\title{
Family-Based Language Learning: A Case Study of the Ponosakan Language Maintenance in North Sulawesi
}

\author{
Mu'jizah $^{1}$, Retno Handayani ${ }^{2}$, Dian Palupi ${ }^{3}$, Erlis Nur Mujiningsih ${ }^{4}$ \\ \{retno.hdyn@gmail.com²,dplp80@gmail.com ${ }^{3}$ \} \\ Badan Litbang Diklat, Kemenag ${ }^{1}$, Badan Pengembangan dan Pembinaan Bahasa ${ }^{2,3,4}$
}

\begin{abstract}
One of the endangered local languages in North Sulawesi is Ponosakan. This study aimed to preserve the sustainability of Ponosakan by means of qualitative methods, such as story telling, singing songs, and revitalisation of the language function for communication within the families. The approach was taken by introducing the vocabularies of the things around their dwelling places, introducing folk-tales, myths, local narratives, games, folksongs in daily conversation. Instead of parents, village leaders, and school teachers who are still familiar with the language use are assigned to teach the Ponosakan. Learners are required to retell everything they learned in Ponosakan language with the hope that their language proficiency will improve. The study has shown that children and their families in Ponosakan actively use the language at home, and the Ponosakan language has eventually been revitalized.
\end{abstract}

Keywords: Language Learning; Language Transmission; Family Domain

\section{Introduction}

Indonesia has abundance of cultural heritage, and one of them is the language. There are about 718 local languages in various places from the Western regions to the Eastern regions of the country. Rather than being developed, the local languages are becoming less popular amids the flux of foreign cultures and modern technology. Many languages have been dormant, among them are the Retta language in East Nusa Tenggara, the Saponi language in Papua, the Letti in Mollucas, and Ponosakan in North Sulawesi.

Sulawesi as one of the big islands in Indonesia contains various local languages. The Center of Language Learning and Reasearch in Indonesia has identified around 58 local languages used in Sulawesi, one of them is the Ponosakan language. According to the Center of Language Learning and Research, the Ponosakan ranks between $81-100 \%$ among the other local languages used in Sulawesi based on dialectometric calculation [1]. Summer Linguistics Institute identified the Ponosakan language in Sulawesi with similar name, the Ponosakan [2]. This language is being used in Tababo village, Belang subdistrict, Southeast Minahasa regency, North Sulawesi. Nevertheless, most of the people whose main livelihood are coconut farmers and fishermen rarely use the Ponosakan for daily communication.

Ponosakan belongs to the category of dormant language since most of its users are elderly people above 45 years of age. Lewis et.al. has identified that a language can be considered as 'endangered' when it is abandoned or neither taught nor used by the young community so as to 
lose its social functions [3]. In its local domain, i.e., in Tababo village, only around 60 people practiced the language. Those younger generation below the age of 30 no longer used it and became passive speakers of the language. They know a number of vocabulary but cannot say or use it in communication. Even children only recognize a few number of vocabulary.

Thus the endangered condition must be overcome to save Ponosakan language by means of language learning. The attempt of language learning is done by persuading people to reuse the language through nonformal learning as one way of the revatilizing or reempowering the Ponosakan language. The problem is to choose the right method of learning Ponosakan language to develop its sustainability. The ultimate objective is to find a way in which the Ponosakan language can survive through the language learning.

Basically, there are several method which could be used for language revitalization, one of which is through formal learning at school with teachers and students in local language class. Some challenges which occured were, (1) limited number of teachers who master Ponosakan language, (2) limitation of local language learning in formal scheme which was done only in certain level, (3) limited time in which students learn their local language in class, (4) limited opportunity for students to use their local language once they graduate because the environment rarely use the language. Based on those challenges therefore learning language in nonformal scheme is carried out in family basis to revitalize Ponosakan language. Family is the core means of language learning, since folklore, myths, folksongs, traditional game, are known and being used in the family. Those cultural works contain local cultural wisdom of Ponosakan ethnic. Through language learning in family domain, this study wants Ponosakan people to actively use their own language. If this succeed, people will reuse Ponosakan language. By using the language, Ponosakan language revitalization could be more developed.

\section{Literary Studies}

Education can be achieved through formal, non-formal, and informal schemes. Learning in non-formal education takes part in manpower development. Mambili (2004) in Syamsi said that operationally, non-formal learning or education can be defined as an organized, structured, and systematized learning service which can be delivered outside the formal framework o school system to certain groups for specific purposes in low budget, both in terms time and resource. Napitupulu in Syamsi also stated that non-formal education is organized outside of school system, lasted a lifetime, run on purpose, planned, and on regular basis to actualize human potential [4].

Family Education has extremely important role since each individual gets his/her first education from his or her own family. In the family, an individual is educated to become a good child with good manners and etiquette, and with appropriate moral qualities. Environment that become determinant of the success or unsuccess of individual education is non-formal environment. The environment demands the application of education that has been obtained by an individual both from family domain and formal environment [5]. Apart from this, a non-formal education also includes the education of life skills, early childhood education, youth education, women empowerment education, literacy education, skills education and job training, equality education, and other education that is addressed to develop potential students with an emphasis on mastery of knowledge and functional skills also professional attitude and personality development [6].

Education through non-formal learning can also be done with a participatory approach. Participatory learning in running of non-formal education is the activity of learning that is 
more to the activeness and participation of the learning citizen. Participatory learning is also meant as a learning resource effort to involve the learning citizen in the learning activity. The involvement of learning citizen is realized in three stages, those are program planning, program implementation, and program evaluation of the learning activity [7].

Kamma (2016) discussed about the efforts made to maintain and revitalize Ponosakan language. The effort to maintain Ponosakan language includes motivation. Motivation is built so that the speakers of Ponosakan language persist in using the language, also sympathize and love the language by continuously studying cultural wisdom contained in it. Ponosakan language building to its speakers as the effort of language revitalization is done according to activities in details as follows, (1) to increase speaker's proficiency of Ponosakan language that includes listening, speaking, reading, and writing skills, (2) cultivate a positive attitude to Ponosakan language by doing writing contest of literary works, arts, customs, and culture of Ponosakan, or tribute to meritorious and high achiever figures in the development of Ponosakan language, (3) to expand the distribution of Ponosakan language use by printed and electronic media, and virtual device [8].

\section{Methodology}

Language learning in terms of revitalization effort is the effort of transmition of language knowledge. Method that is used is non-formal learning method, it is learning at the outside of classroom from parents, traditional elders, and teachers who still master Ponosakan language to children by using participatory approach. This non-formal learning is done in the form of playing, storytelling, singing activities, and habit of communicating in Ponosakan language in the family realm.

The approach in the learning is expected to support the process of mastering student's skill. The approach is meant to be a method to start the learning. According to Wahjoedi in Hanum and Rahmawati, approach of learning is a method to manage learning acitivity and student's behavior so they actively do their learning tasks that they can achieve an optimum result of learning. Learning approach can also be a point of view or starting point to a learning process, which is related to the occurance of a general process that accommodates, inspires, strengthen, and underlies the learning method with theoretical coverage [9].

The learning of Ponosakan language aims to increase the active speakers of Ponosakan language. This non-formal learning uses learning material or media to transfer language skill from the older generation, father, mother, to their children, the younger generation. Material and media of Ponosakan language learning that are used in the non-formal learning for people of Ponosakan include grammar or language system, pocket dictionary, songs, stories, folktale, and traditional games that belonged to them and have been inventoried. The inventory stages follows Hinton's opinion which advises that one of the real efforts that could be done to return the use of the nearly vanished language is to collect linguistic publication, field notes, and voice recording as a part of resource creation based on community and archaives [10].

Those material and media that are available in the community are brought back to be instiled to the younger generation in non-formal learning that starts with family. Family is the target in this learning because family is a defense basis of a language. As Grimes stated that the main factor of a language extinction is because parents do not teach their local language or mother tounge anymore to their children [11]. Baharuddin Salam in Adawiyah, et al stated that family is naturally the first and foremost educational institution through the media of games [5]. Furthermore, the next step of the Ponosakan language learning program is the selection of 
ten nuclear families as the learning models. Families that participate in this learning are the core family that consists of father, mother, and children who will learn and teach Ponosakan language. The learning is customized according to their background of lives.

\section{Result and Discussion}

\subsection{Material and Media of Ponosakan Language Learning}

Ponosakan language has its own language system as other local language in Indonesia. This language system becomes a basic knowledge in linguistics. Ponosakan language sound is taught to children in the form of regional vocabularies delivery which were said by parents at home. Parents' speech that mentions vocabulary of Ponosakan language to their children, familiarize the latter to listen the language sounds, also to know certainly the meaning of vocabulary spoken by their parents. Sometimes parents point to something, invite to do something, ask for opinion, invite the kids for storytelling, or even tell about something using Ponosakan language. Language sounds, words, and sentences that are Ponosakan's language system become child knowledge which are oftenly spoken by parents and considered as nonformal learning material of Ponosakan language.

Meanwhile, bi-lingual, Indonesian-Ponosakan dictionary has also been compiled by Sulawesi Language Center in 2016. The Indonesia-Ponosakan dictionary could be utilized by beginners who have never been exposed to know Ponosakan language, as for PonosakanIndonesian one could be utilized by active and passive speakers of Ponosakan language. This dicitionary contains at least 200 basic vocabularies of Swadesh and several other vocabularies which are actively used by parents to communicate.

Language is also used in literature, especially oral literature which has been traditionally passed down from generation to generation. Apart from grammar and dictionary, material taught are tales, myths, folklore, folkgame, and folksongs of community of Ponosakan language. Folktales and folksongs are chosen for it can attract children and parents' attention. Ponosakan people have several oral literature. The first oral literature is folktale on history that is "Mosia ayuon pitu no bangsa" dan "Dinaitan Daerah Ponosakan". These stories are interesting as the story of "Mosia ayuon pitu no bangsa" tells about the origin of the nation (ethnic) and the story of "Dinaitan Daerah Ponosakan" tells about the origin of the village. There is also folktale that narrates the origin kiting-kiting dance.

There is also another story, an etymology of name of Tombaku village. Tombaku is a danger-prone area. It means 'falling stone'. The name was carried when the country was attacked by infectious deaseas that caused many people to die. They left the country and spread to several areas, i.e. to Molompar and Liwutung. People who inhabited Liwutung then spread to Ratahan, Tondano, and Minahasa. This story exposed about the migration of people to several places and their original relations.

The second form is folksongs. There is a song which is accompanied by a dance, "Membulo Payow" that means "Menanam Padi Ladang [Planting Rice Fields]". Couple dance "Membulo Payow" tells about a married couple who left for clearing the field in which rice will be planted. They are clearing out the fields by hoeing, and then take out the hoed-grassess to plant rice fields. After the fields are cleared, they start to plant rice on it. Within several months, the rice are growing fruitful so they are to chase away the birds that perch and eat of the rice. After the rice turns yellow and is ready be harvested, the couple then harvest them. To be grateful to God's blessings, this couple pray and then have a thanksgiving party. 
There is also another folksong, i.e. Tiyu Singkay Gowi'i that means 'Night and Afternoon Sleep'. This is a kind of lullaby which means that sometimes it is difficult to sleep in the afternoons and at nights because of the memory of father and mother. Although living in poorly, parents prefer to live with their children and grandchildren. This song gives a message that it is better to be united with the family to face the hardship together. Apart from it, there are other folksongs "Tababo Kosandoanku" that means [Tababo Kerinduanku] "My longing of Tababo" and Tawawo Bonuakku that means ['Tababo Desaku'] 'Tababo My village'. These song tell the story of longing to the village and Ponosakan people as relatives and brothers, also the song for long life prayer. Folksongs, Tiyu Singkay Gowi'i and Tawawo Bonuakku can be seen in table 1 and 2 as follow

Table 1. Folksong Tiyu Singkay Gowi'i

\begin{tabular}{|c|c|c|}
\hline Bahasa Ponosakan & Bahasa Indonesia & English \\
\hline \multirow{5}{*}{$\begin{array}{l}\text { Tiyu singkay gowi'i } \\
\text { Akuoi deamo kotiu } \\
\text { Kanak mokosandon Ko'on bonuaku } \\
\text { Koniyon nohutun Ina bo ama' } \\
\text { Konoyon nohutun utasku kominsan }\end{array}$} & Disaat tidur siang dan malam & When sleeping at noon \\
\hline & Ibu tidak bisa tidur & and night \\
\hline & Karena teringat & Mother cannot sleep \\
\hline & halaman & For the memory of her \\
\hline & & hometown \\
\hline \multirow{2}{*}{$\begin{array}{l}\text { Paka mo susa deyak mangoi ari' bo } \\
\text { ompu }\end{array}$} & Biar hidup susah & \\
\hline & Tolong bawakan pulang & Though life is hard \\
\hline \multirow[t]{6}{*}{ Koniyon nohutun utasku kominsan } & Karena lebih suka & Please help bringing \\
\hline & Anak dan cucu & back home \\
\hline & Untuk tinggal serumah & For its better \\
\hline & & Children \\
\hline & & grandchildren \\
\hline & & 10 ilve logether \\
\hline
\end{tabular}

Tabel 2. Folksong Tawawo Bonuakku

\begin{tabular}{|c|c|c|}
\hline Bahasa Ponosakan & Bahasa Indonesia & English \\
\hline Tawawo bonuakku & Tababo desaku & Tababo, my village \\
\hline Noyayuk ron kon mataku & Telah jauh dari mataku & Been far away of my \\
\hline Singkai gowi-I deak mokotio & Siang malam tak bisa tidur & sight \\
\hline Mokosandow kon bonnuakku & Teringat selalu desaku & $\begin{array}{l}\text { Cannot sleep at noon } \\
\text { and in the night }\end{array}$ \\
\hline Konion nohutun inak bo amakku & Disitu tinggal ibu dan bapakku & Always remember of \\
\hline Takin utas-utasku kominsan & Beserta saudara-saudaraku semua & my village \\
\hline Mosia deak kolionganku & Mereka tidak akan aku lupakan & \\
\hline Tawawo bo bonuakku & Tababo desaku & $\begin{array}{l}\text { There, my father and } \\
\text { my mother live }\end{array}$ \\
\hline Oh......Tohu kawasa naton & Oh........Tuhan kami & Along with all my \\
\hline Akuoi mohalik kon nimu & Aku memohon kepadamu & brothers \\
\hline Mononoi roman mowiya kominsan & Semoga mereka semua umur panjang & I won't forget them \\
\hline Kon tawawo kinotawianku & Di Tababo yang aku cintai & Tababo, my village \\
\hline Umpaka akuoi ayuon kon onda & Meskipun aku berada dimana & \\
\hline Kon gina moiwo mowui & Di hati ingin pulang & Oh...our Lord \\
\hline Insya Allah Ridha Tahu Kawasa & Insya allah dengan izin Tuhan & I beg you \\
\hline \multirow[t]{3}{*}{ Tawawo bonuakku } & Tababo desaku & $\begin{array}{l}\text { I hope they will be } \\
\text { long live }\end{array}$ \\
\hline & & In Tababo that I love \\
\hline & & $\begin{array}{l}\text { Though anywhere I } \\
\text { live }\end{array}$ \\
\hline
\end{tabular}




\begin{tabular}{|c|c|c|}
\hline Bahasa Ponosakan & Bahasa Indonesia & English \\
\hline & & $\begin{array}{l}\text { Desire in my heart, to } \\
\text { go home } \\
\text { Insya allah with God's } \\
\text { permission } \\
\text { Tababo, my village }\end{array}$ \\
\hline
\end{tabular}

The third form is folkgame. The game inventory is considered adequate mainly that Ponosakan origin as mawetik. Mawetik is a game to crack something to blossom. The items to bloom in this game are rice and corn seeds. To get the rice or corn, people have to work so children are enthusiastically help their parents to work. This game shows the intimacy, cooperation, and certainly the healthy. Apart from this game, there is also a game, [Si Kaya dan Si Miskin] The Rich and The Poor which is sung. Two group lines facing in this game. The first group as The Rich and the second one as The Poor. The Rich group sings and step forward at once to ask a child of The Poos. So does The Poor when they have no more children, they ask a child to The Rich in exchange. A child is symbolized as the gift of God that is most loved in a family. The game teaches children to share mutually of everything they have in rich or poor condition.

There is local wisdom concerning the important concepts belonging to Ponosakan people in the oral literatures, e.g. concept of koniyan nohutun utasku kominsan 'we are all brothers'. This expression shows that their relationship in the village is so close since they are originally brothers. Their kinship is also represented by the song as the longing for the village. Bonuak is the term for village. The joyful life in the village with an intimate kinship makes the village is always longed for. That is the song that sung in Tawawo Bonuakku 'Tababo, My village'. The song also contains a prayer for long lives of their brothers 'roman mowiya'. Apart from this, it also contains several words showing the kinship, i.e. inak 'mother' and amak 'father'. They also have treasures of words for body parts in the song, like mokotiyu 'mataku'. The richness of vocabularies that keep the wisdom of Ponosakan people which is used as one of materials of language learning to revitalize Ponosakan language.

\subsection{Family based of Ponosakan Language Learning}

Family is not self-contained, closed off to other social institutions and economic conditions. Furthermore, the family is shaped by history and power, at times reproducing ideological values and power inequalities established from colonial times. Such a broadened perspective is critical to theorizing the prospects of the family in maintaining a marginalized language [12]. One that affects the learning process in the socio-educational model proposed by Gardner (1985) is parental encouragement. This parental encouragement can motivate children in an effort to learn the local language during the process [13].

Language learning in non-formal scheme as an effort to revitalize a language is one of the methods in re-empowerment of a language, mainly to local language that is almost extinct. Hinton stated that language revitalization in an attempt to restore an endangered language at a better level of usage in society after experiencing a decrease in it. Furthermore, Hinton also stated that main task of language revitalization consists of two things, those are teaching language to those who do not know the language and the use of language in broader situation by people who learn the language [10].

Basically, language learning in non-formal way in the realm of family is done in three stages. First stage is inventory and identification of research's result that are related to the structure of Ponosakan language, from the system of phonology, morphology, syntax, and 
semantics. Research on structure of language is very important to make the learning instruments. Other than that, inventory of the list of the words which later on is composed to be a dictionary of Ponosakan language as a means of words meaning search. This dictionary is extremely important because Ponosakan community has been less familiar to the language.

Later on, the team also collected materials of language learning in the form of folklore, folksong, myths, and traditional games in Ponosakan language. After that, a survey was done in the field. In this stage, the team must approach the community by visiting stakeholders, indigenous people, traditional elders, and the scholars. This attempt was done so that the important people in the community would support the language learning program so that it would run smoothly. The team, at the stage, invite them to gather with the indigenous people and stakeholder who are a part of Ponosakan community. Through the Kumtua (Hukum Tua 'Old Law'), the team visit several families who are willing to be the model of learning. Although the Kumtua previously appoint several families to be the learning participant, the learning language team must do the approach as well so that emotions are intertwined. As the initial model of this learning, ten families that are committed to teach the language to their children are appointed.

Second stage is the learning of Ponosakan language stage in their own families. Basically, this learning stage is done with no time limitation. In the family, parents and children must use their local language in their daily activities. As stated by Karimova and Israilova that to learn and develop language, one has to communicate. Student needs to participate even if he/she has not spoken the language fluently. Someone who tries to speak and participate in conversation, though he has not master the language yet, is better than the one who is shy to speak. In such learning, student needs a partner to practice regularly. This is beneficial in the learning of a language so it can create a unique competitive environment between partners [14]. In this learning stage, each family as the child's learning partner can teach various stories, local songs, and history in Ponosakan language also play with folkgame. They also learn many things that related to the environment of their daily life, such as household utensil, making of Ponosakan special cake, gardening, or technique of fishing and catching fish from the sea.

The techniques of language learning were done in two ways. Firstly, parents and children in the core family learned naturally at home. Secondly, once in every two-weeks families were gathered in a certain plaee to evaluate the development of their ability. The method of reactivating the language in a family realm is considered effective and useful to reactivate the local language usage, mainly in the family realm by using a relaxed and comfortable system of learning, and by way of playing game. Children will be taught the language naturally without time limitation. Thus, the sponsor of this activity was the Chief of Tababo village or 'Hukum Tua Desa', i.e. Mr. Yahya Ilolu and Mr. Ustadz Abdul Kohar Sampage. As for the tutor, two Ponosakan language speakers-who work as teachers-were appointed, i.e., Mr. Erfi Liu and Ms. Huzaima. Through this method, their mastery, skills, and proficiency of Ponosakan language were expected to increase. Much more than that, knowledge, culture, and local wisdom will also be known, mastered, and understood by the young generation of Ponosakan tribe. This family based learning uses the method that is easily digested by the family member leisurely. Practice of Ponosakan language use is carried out in the family and on a certain social community activity which is related to the community's need. For children, the learning is done by playing while digging the treasures of the folkgame. For teenagers, the learning is carried out through the mosque youth community. As for the parents, practice of Ponosakan language could be done through the social meetings, like arisan 'lotery club', PKK (a community's organization to empower women to participate in country's development), the village's meetings, and other social meetings. 
Once in two-weeks, these students gather in the traditional house to evaluate the learning activity at home. In this evaluation, tutors play a very important role to monitor the skills of the family. One of the ways is every family submits their notebook of the learning at home and shows their language ability in front of the other families. Tutors will correct for any mistake. This method is considered effective since parents and children are enthusiastically expose their language ability. Tutors also invite children to learn by playing with children game of Ponosakan, tell a story or tale.

During the meeting, a simulation of listening technique was practiced, i.e. re-listening and pronouncing. The correct speech is exemplified and the students repeat the words. The utterance involved phoneme, words, phrase, and a brief sentence. The other model was the tutor gave instruction and the students were to follow based on it. The other technique was listening and guessing. In this technique, tutor took something and asked students to guess and describe it. Chain listening technique was also done as a variation. Tutor wishper a message to a student who then wishpered the message to the other student and so on. The last student should say the message loudly. The tutor then examined whether the message was as correct as the first message or not. To attract the students, tutor also told a story. Later on, the students were asked to guess the end of the story's plot by using their own language. Another technique was by dividing the students into groups and asked them to make a story, after finishing it, one of the students was asked to tell the result of their stories in front of the class. In the middle of the story-telling, the tutor stopped it and asked another group who were listening to the story to proceed the story, and so on until the end. On the other occasion, the students were invited to re-tell this story.

They were not only learning, but also had to demonstrate several games. Parents even told stories to their children. After the story-telling session was over, the children were to ask about anything related to the stories - they just listenend - in Ponosakan language. In that learning, they were also asked to demonstrate their knowledge about numbers, body parts, and colors. Ibu Tini, a humorous elder, had been invited to entertain the participants. She demonstrated how to serve special rice, known as 'jaha', to village mothers. Ibu Tini used Ponosakan language in her demonstration of the cooking.

On the following stage, a language festival was held. The purpose of this festival is to motivate Ponosakan people to preserve their own language. In this festival, students showed the proficiency of each family in using Ponosakan language. Each family included their children were speaking Ponosakan language according to the theme chosen. Children sang, a traditional song on the stage - guided by Ms. Huzaimah, a kindergarten teacher who acted as the tutor. She demonstrated how to teach children groups to learn folkgames and to understand folklores. The festival on language proficiency was held at the Tababo village hall and was attended by local community and the local government officers. Even the government staff of Southeast Minahasa District and North Sulawesi Province attended this festival. Besides that, the festival offered various competitions, such as speech contest, smart and master contest on the mastery of vocabularies of Ponosakan language, and a competition of telling a story in Ponosakan language.

\subsection{The Appreciation of Learning of Ponosakan Language}

Language learning which was done in a non-formal domain as one of the methods of language revitalization, in the end got some appreciation from the stakeholders, traditional elder, and the community. By the learning in the form of revitalization, their awareness has been arisen that they cannot lose their cultural asset, their language. As in the language 
contains local thinking and wisdom. If the language is lost, then everything related to the treasure will be lost, too. Therefore, the learning gives a positive effect. Socialization has been done to disseminate information about the attempt to revitalize the the endangered local language. Socialization to disseminate information was done through printing and electronic media. News about this revitalization was printed on a newspaper, Tribun Manado on 12 June 2016 and 8 August 2016. An electronic media publication was also done to broadcast the activity through RRI Manado and TVRI Manado by a delay broadcasting on Saturday, 4 June 2016 and Friday, 7 October 2016 at 19.00 Eastern Indonesian Time.

By means of the socialization, local government and people were expected to have the information on the importance of maintaining their local language. The government become more concern so as to plan to issue certain policies that the local language in an area will still be protected and become the cultural asset of every place. On the other side, people will be more sensitive and aware to maintain their own language by passing their language ability to their children. This socialization process is continued by 'UPT' technical implementation unit in North Sulawesi Language Center. Language Center and local government are expected to develop the learning process continuesly, to issue policies related the revitalization of the endangered languages in North Sulawesi, or to facilitate local government to make derivative regulation about local languages which are exist in their areas.

After the Ponosakan language learning taking place in Tababo village, Belang sub-district, Southeast Minahasa Regency, the community's awareness to maintain Ponosakan language has been awakened. Language atmosphere of the use of Ponosakan language arises as parents get excited to teach the Ponosakan language to children. The awakening of the community's awareness to maintain and preserve their own language is expectred to increase continuously up to the next generation. Other thing that are prioritized in this learning activity is the transmition of Ponosakan language ability to the children. Thus the learning can continue and be sustainable. By this learning, the stakeholders mainly in the Southeast Minahasa Regency will pay more attention to local language preservation, not only to the Ponosakan language, but also to several ones in Southeast Minahasa Regency. The attention to and preservation of local language given by the stakeholders are stated in (1) looking for legal guidelines to Ponosakan language preservation, (2) proclaiming "Regional Language Day" to use only the Ponosakan language on a certain day within the community, and (3) Kumtua (Chief of the village), head of religion, and the community's commitment to preserve of Ponosakan language promised to keep continuing the language learning and passing it to their children.

\section{Conclusion}

Language learning in the non-formal realm as one of the attempts to maintain Ponosakan language runs well. This effort can inspire the community of the language belongs to. People are aware that the language they own is a cultural asset that cannot be lost. The desire to relearn Ponosakan language can improve language vitality. If in the past, only people at 45 years old master the language, it is now by this learng, ages under 45 years old-adults, teens, children — can understand Ponosakan language.

Learning system with stages that were done as mentioned in the above needs to be developed countinuously, primarily on the learning facilities. Several challenges encountered must also be overcome as an experience. Coordination and cooperation with the stakeholders and national broadcasting stations-TVRI, RRI, and media went well. This socialization by using media can make people of North Sulawesi, spesifically Southeast Minahasa can be 
compelled to pay attention to the language they own. By this learning then, parents are more enthusiastic in teaching their children to use Ponosakan language at home. Moreover, an idea - to use Ponosakan language in social programs which are attended by the elders like Qoran studies and custom gathering - came up.

The activities has an impact on the increasing number of Ponosakan language young speakers. This can be seen by the teaching of Ponosakan language start from an introduction of body parts and games to kindergarten students. This method is also done to children at a Qoran studies group around Ponosakan mosque that is led by Ms. Huzaimah. Even the village youth organization will be invited to support this learning by Mr. Erfi. Although the children are passive speakers of Ponosakan language currently, the desire to learn their own language begins to emerge.

By the revitalization or Ponosakan language learning, stakeholders realize that they have to save local languages that are under their control. Furthermore, they that mainly in Southeast Minahasa also give their attention to languages preserverence which in the form of (1) finding legal guidelines in preserving Ponosakan language, (2) declaring "local language day" on a certain day in the community and (3) Kumtua (Chief of the village), head of religion, and the community's commitment to preserve of Ponosakan language and will keep continuing the language learning to their children. Thus, the learning activities are expected to be able to raise public awareness to maintain Ponosakan culture and language. Stakeholders in sub-disctrict, regency, and province level help it to be realized so that this cultural treasure remains sustainable and Ponosakan language will not extinct from the earth Tababo.

\section{References}

[1] B. Bahasa, Bahasa dan Peta Bahasa di Indonesia, Edisi Keen. Jakarta: Badan Pengembangan dan Pembinaan Bahasa (2019)

[2] SIL, Bahasa-Bahasa di Indonesia, Edisi Kedu. Jakarta: SIL International Cabang Indonesia (2006)

[3] C. D. F. Lewis, M. Paul, Gary F. Simons, "Ethnologue: Language of the World," SIL International (2015)

[4] I. Syamsi, "Metode Pembelajaran Partisipatif untuk Penyelenggaraan Program Pendidikan Nonformal dalam Masyarakat," Maj. Ilm. Pembelajaran, vol. 6, no. 2 (2009)

[5] Sulfasyah, "Implikasi Pendidikan Nonformal pada Remaja," Equilib. Pendidik. Sosiol., vol. IV, no. 1, pp. 1-8 (2015)

[6] D. Yatimah, "Dampak Implementasi Metode Pembelajaran Berbasis Masalah Pada Tutorial Program Paket B Binaan Pkbm Al Ishlah Jakarta Timur," J. Nonform. Educ., vol. 2, no. 1 (2016)

[7] D. Hidayat, "Strategi Pembelajaran Partisipatif dalam Meningkatkan Hasil Program Pendidikan Nonformal di Kabupaten Karawang," J. Nonform. Educ., vol. 2, no. 1 (2016)

[8] A. Kamma, "Usaha Pemertahanan Dan Revitalisasi Bahasa Ponosakan," Kadera Bhs., vol. 8, no. 2, pp. 209-218 (2016)

[9] S. Hanum and R. Rahmawati, "Implementasi Pendekatan Fungsional dalam Pembelajaran Bahasa Arab Melalui Metode Community Language Learning," J. Ilmu Bhs. Arab dan Pembelajarannya, vol. 9, no. 2 (2020)

[10] L. Hinton, "Revitalization of Endangered Language," in The Cambridge Handbook of 
Endangered Languages, London: Cambridge University Press (2011)

[11] B. F. Grimes, "Kecenderungan Bahasa untuk Hidup atau Mati Secara Global (Global Language Viability): Sebab, Gejala, dan Pemulihan untuk Bahasa-Bahasa yang Terancam Punah," in PELLBA 15, pp. 1--39, Jakarta: Penerbit Kanisius (2002)

[12] C. Smith-Christmas, Family Language Policy: Maintaining an Endangered Language in the Home. UK: Palgrave Mascmillan (2016)

[13] C. F. Man, S. Sharif, A. L. J. May, R. Talin, S. Singh, and B. Singh, "The effects of drama-based activities as a language learning tool on learners' motivation in NonMalay-medium national schools in Malaysia," Indones. J. Appl. Linguist., vol. 10, no. 3, pp. 603-614 (2021)

[14] J. S. Karimova and D. A. Israilova, "Modern methods of language learning," Journal of Critical Reviews, vol. 7, no. 5 (2020) 